\title{
Metabolic Disease and Chronic Kidney Disease among Women in Indonesia: A Cross-Sectional Population-Based Survey
}

\author{
Tri Wahyuni ${ }^{1 *}$, Lianawati ${ }^{1}$, Joanggi Wiriatarina Harianto ${ }^{1}$, Ery Khusnal ${ }^{2}$
}

\author{
${ }^{1}$ Faculty of Health and Pharmacy, Universitas Muhammadiyah Kalimantan Timur (UMKT), Kalimantan Timur, INDONESIA \\ ${ }^{2}$ Faculty of Health Sciences, Universitas 'Aisyiyah Yogyakarta, Yogyakarta, INDONESIA \\ *Corresponding Author: tw879@umkt.ac.id
}

Citation: Wahyuni T, Lianawati, Harianto JW, Khusnal E. Metabolic Disease and Chronic Kidney Disease among Women in Indonesia: A CrossSectional Population-Based Survey. Electron J Gen Med. 2020;17(2):em191. https://doi.org/10.29333/ejgm/7808

\section{ARTICLE INFO}

Received: 6 Nov. 2019

Accepted: 4 Jan. 2020

\begin{abstract}
Purpose: These study aims were to determine the prevalence and the associated factors of chronic kidney disease among women in Indonesia.
\end{abstract}

Methodology: This cross-sectional study used the data from the Indonesia Family Life Survey wave 5 (IFLS-5) during year 2014 to 2015. This cross-sectional national population survey used a multistage stratified random sampling to select the respondents to response to a structured questionnaire interview, laboratory test and anthropometric measurements. 14,141 women passed the inclusion criteria for the analysis. Multivariable logistic regression was used to determine the association. The average age of the respondents involved in this research was 37.40 years old.

Results: Only a small percentage of 1.07 percent of respondents noticed the prevalence of chronic kidney disease. There were 151 out of 14,141 respondents reported the presence of CKD. The final model of a multiple logistic regression indicated that cardiovascular and cholesterol were significantly associated with the Chronic Kidney Disease (CKD) among women in Indonesia. Other significant covariate factors were age (above 50 years old), overweight or obesity and smoking.

Conclusion: Metabolic factors include cardiovascular and cholesterol as well as age, body mass index (BMI), and smoking were associated with CKD among women in Indonesia.

Keywords: chronic kidney disease, cardiovascular disease, women, metabolic disease

\section{INTRODUCTION}

Kidney disease is defined as any abnormality in kidney function, initially occurring without changes in glomerular filtration rate (GFR) which then causes a decrease in kidney function, and can lead to the development of chronic kidney disease (CKD) to end-stage kidney disease (ESRD) (1). Ten percent of adults in the world have experienced the effects of Chronic Kidney Disease (CKD). CKD is 1 of many primary causes of mortality worldwide that has a devastating impact on people and their families. The government, through the commemoration of World Kidney Day and International Women's Day in 2018, jointly explained that the importance of health in women, especially kidney disease. Women are significant contributors to the community and their families, so the importance of understanding the distinctive aspects of kidney disease in women can prevent chronic kidney disease as early as possible in women themselves (2).

Patients with CKD are usually not aware of the symptoms of the illness. This is because the kidneys in humans can tolerate interference with kidney filtration and function. Even the body can survive with only one kidney functioning. The adverse effects of people are not so concerned with health and criminal function. So that more patients are diagnosed with kidney conditions that are already bad. Kidney disease is one of the incurable diseases. Proven kidney disease continues to get worse even though treatment has been done. When the kidneys are unable to function, the treatment is dialysis or transplantation. This is done in patients with kidney failure with end-stage kidney disease (ESRD). So there is prevention needed to avoid the effects of kidney failure to end-stage kidney disease (3).

People with CKD have a significantly higher risk of morbidity, mortality, hospitalization, and utilization of health services compared to people without CKD. The number of CKD has increased significantly from 1988 until now. Stage 1 CKD decreased because Stage 3 CKD increased to $6.5 \%$ from 2003 to 2006. The prevalence of stages CKD 4 and 5 increased twofold higher from 1988 to 1999, but has remained stable since 2002 at $0.6 \%$ (4). Low CKD awareness, like many non-communicable diseases (NCDs), CKD has low awareness, usually less than $20 \%$, or at a more advanced stage and in developed countries. Less than $5 \%$ of people with an estimated GFR (glomerular filtration rate) of less than $60 \mathrm{ml} /$ minute per $1.73 \mathrm{~m} 2$ and proteinuria as a marker of kidney damage are known to have CKD in the United States. In those who suffer from stage 3 CKD, consciousness is only $7.5 \%$, and less than $50 \%$, for stage 4 (5). 
Chronic kidney disease is a concern for problems in developing countries. The results of a systematic review in 2015 revealed that the number of women in both developed and developing countries had a higher proportion suffering from CKD. People from high-income countries nearly 109.9 million have CKD (men-48.3 million, women-61.7 million) while the burden is 387.5 million in lower-middle-income countries (men-177.4 million, women - 210.1 million) (6). Data from previous studies revealed that the prevalence of CKD among women in Indonesia was reported separately, Jakarta (2.9\%), Bali (3.7\%), Surabaya (2.3\%), and Yogyakarta (2.4\%) which is higher than male overall (7). These study aims were to determine the prevalence and the association factor of chronic kidney disease among women in Indonesia.

\section{METHODOLOGY}

\section{Study Design and Sampling}

The data represented in this study used data from the Indonesia Family Life Survey wave 5 (IFLS-5) organized by Rand Corporation. The IFLS-5 was conducted in 2014-2015, with 16,204 households and 50,148 individuals interviewed. This data represents all of Indonesia using stratified random sampling to select respondents from provincial to residence level. This study uses a cross-sectional study design with inclusion criteria: people who have 18 years of age or older and are female. Exclusion criteria: people who do not have complete data or unknown data. The total respondents in this study were 14,141 .

\section{Measurement}

The outcome of this study was chronic kidney disease. Chronic kidney disease (CKD) referred to the person who has kidney disease (except for tumor or cancer) diagnosed by doctor/paramedic/nurse/ midwife. The independent factors were 1) Sociodemographic factors include age, marital status, education, ethnicity, residence, and body mass index (BMI). The BMI was calculated as weight in $\mathrm{kg}$ divided by height in meter squared and classified based on Asian criteria categorical (polychotomous): underweight $(<18.5 \mathrm{~kg} / \mathrm{m} 2)$, normal weight (18.5 to $22.9 \mathrm{~kg} / \mathrm{m} 2$ ), overweight (23.0 to $24.9 \mathrm{~kg}$ ) $\mathrm{m} 2$ ), obesity (>=25 kg/ m2) (8) and was classified to dichotomous variable in multivariable analysis. 2) Metabolic disease factors include hypertension, diabetes, cardiovascular, cholesterol. 3) Behaviour factors include smoking, modern selftreatment, traditional self-treatment, medicine taken for hypertension, medicine taken for cholesterol.

\section{Statistical Analysis}

This research is an observational analytic study. Descriptive research is used to determine the characteristics of this study. Inferential research is used to determine the factors associated with chronic kidney disease. At the bivariate stage using simple logistic regression. Initial models include independent variables that have a p-value of the Wald test $<0.25$ (9). Backward Elimination is used to determine the factors associated with CKD in the multivariable model stage by using multiple logistic regression. Multicollinearity between the independent variables was checked by using the STATA version 10 software package. The results were presented as adjusted odds ratio (ORadj) and their 95\% confidence interval (CI). The interpretation was presented as no association if
Table 1. Table on top of a column (font size: 9)

\begin{tabular}{|c|c|c|c|}
\hline \multicolumn{2}{|c|}{ Characteristic } & Number & $\%$ \\
\hline \multicolumn{4}{|c|}{ Sociodemographic } \\
\hline \multirow{5}{*}{ Age } & $<35$ & 6,904 & 48.82 \\
\hline & $>=35-<50$ & 4,479 & 31.67 \\
\hline & $>=50$ & 2,758 & 19.50 \\
\hline & Mean $( \pm$ SD) & $37.40( \pm 13.27)$ & \\
\hline & Median (min : $\max )$ & $35(18: 101)$ & \\
\hline \multirow{2}{*}{ Marital Status } & Single & 2,964 & 20.96 \\
\hline & Married & 11,177 & 79.04 \\
\hline \multirow{4}{*}{ Education } & University & 2,202 & 15.57 \\
\hline & Senior High School & 4,132 & 29.22 \\
\hline & Junior High School & 2,856 & 20.20 \\
\hline & Elementary & 4,951 & 35.01 \\
\hline \multirow{4}{*}{ Ethnicity } & Javanese & 9,546 & 67.51 \\
\hline & Sumatra & 1,484 & 10.49 \\
\hline & Bali and East of Indonesia & 2,433 & 17.21 \\
\hline & Others & 678 & 4.79 \\
\hline \multirow{2}{*}{ Residence } & Urban & 8,499 & 60.10 \\
\hline & Rural & 5,642 & 39.90 \\
\hline \multirow{4}{*}{ Body Mass Index } & Underweight $(<18.5)$ & 1,136 & 8.03 \\
\hline & $\begin{array}{c}\text { Normal Weight } \\
(18.5-22.99)\end{array}$ & 4,685 & 33.13 \\
\hline & Overweight $(23-24.99)$ & 2,407 & 17.02 \\
\hline & Obese $(>=25)$ & 5,913 & 41.81 \\
\hline \multicolumn{4}{|c|}{ Metabolic Disease } \\
\hline \multirow{2}{*}{ Hypertension } & No & 12,123 & 85.73 \\
\hline & Yes & 2,018 & 14.27 \\
\hline \multirow{2}{*}{ Diabetes } & No & 13,828 & 97.79 \\
\hline & Yes & 313 & 2.21 \\
\hline \multirow{2}{*}{ Cardiovascular } & No & 13,875 & 98.12 \\
\hline & Yes & 266 & 1.88 \\
\hline \multirow{2}{*}{ Cholesterol } & No & 13,419 & 94.89 \\
\hline & Yes & 722 & 5.11 \\
\hline \multirow{3}{*}{ Smoking } & Behaviour & & \\
\hline & No & 13,725 & 97.06 \\
\hline & Yes & 416 & 2.94 \\
\hline \multirow{2}{*}{$\begin{array}{l}\text { Modern Self } \\
\text { Treatment }\end{array}$} & No & 7,045 & 49.82 \\
\hline & Yes & 7,096 & 50.18 \\
\hline \multirow{2}{*}{$\begin{array}{l}\text { Traditional Self } \\
\text { Treatment }\end{array}$} & No & 11,643 & 82.34 \\
\hline & Yes & 2,498 & 17.66 \\
\hline \multirow{2}{*}{$\begin{array}{l}\text { Medicine Taken } \\
\text { for Hypertension }\end{array}$} & No & 13,717 & 97.00 \\
\hline & Yes & 424 & 3.00 \\
\hline \multirow{2}{*}{$\begin{array}{l}\text { Medicine Taken } \\
\text { for Cholesterol }\end{array}$} & No & 13,976 & 98.83 \\
\hline & Yes & 165 & 1.17 \\
\hline
\end{tabular}

ORadj approached 1.00, a protective effect if ORadj was less than 1.00, and risk factors if ORadj was greater than 1.00 .

\section{RESULTS}

\section{Demographic Characteristic}

There were a total of 14,141 women in Indonesia passed our inclusion and exclusion criteria with an average of age 37.40 ( \pm 13.27 ), $79.04 \%$ were married, $67.51 \%$ Javanese, $60.10 \%$ staying in an urban area and $41.81 \%$ obese. There were people who have cardiovascular, and cholesterol was 266 (1.88\%) and $722(5.11 \%)$ respectively. The Body mass Index contained underweight $(<18.5)$, Normal Weight $(18.5-22.99)$, Overweight (23 - 24.99), Obese $(>=25)$ were $(8.03 \%, 33.13 \%, 17.02 \%$, 41.81\%) (see Table 1). 
Table 2. Prevalence of Chronic Kidney Disease among Women in Indonesia $(n=14,141)$

\begin{tabular}{ccccc}
\hline \multicolumn{2}{c}{ Characteristic } & Number & \% & $\mathbf{9 5 \%} \mathbf{C l}$ \\
\hline $\begin{array}{c}\text { Chronic Kidney } \\
\text { Disease }\end{array}$ & No & 13,990 & 98.93 & $98.75-99.09$ \\
\cline { 2 - 5 } & Yes & 151 & 1.07 & $00.91-01.25$ \\
\hline
\end{tabular}

\section{Prevalence of Chronic Kidney Disease among Women in Indonesia}

The chronic kidney disease (CKD) prevalence among women in Indonesia was $1.07 \%$ (95\% Cl: $00.91-01.25)$. There were 13,990 of the respondents who did not have CKD $(98.93 \%$, 95\% Cl: 98.75 - 99.09) (see Table 2).

\section{Factor Associated with Chronic Kidney Disease among Women in Indonesia}

Simple logistic regression is used to analyse any factors that might be significant with CKD. Independent factors that have a $p$ value $\leq 0.25$ are processed into the initial model of multivariable analysis. The Bivariate analyses indicated that age $(\mathrm{OR}=2.96,95 \% \mathrm{Cl} 1.95-4.47, \mathrm{p}=<0.001)$, marital status $(\mathrm{OR}=1.48,95 \% \mathrm{Cl} 0.95-2.31, \mathrm{p}=0.071)$, ethnicity $(\mathrm{OR}=1.25$, $95 \% \mathrm{Cl} 0.88-1.79, \mathrm{p}=0.210)$, body mass index (OR $=1.77,95 \%$ $\mathrm{Cl} 1.24-2.52, \mathrm{p}=0.001)$, hypertension $(\mathrm{OR}=2.11,95 \% \mathrm{Cl} 1.46-$ $3.05, p=0.000)$, diabetes $(\mathrm{OR}=3.93,95 \% \mathrm{Cl} 2.15-7.16, \mathrm{p}=$
$0.000)$, cardiovascular (OR $=6.51,95 \% \mathrm{Cl} 3.82-11.10, \mathrm{p}=$ $<0.001$ ), cholesterol (OR $=4.17,95 \% \mathrm{Cl} 2.73-6.36, \mathrm{p}=<0.001)$, smoking $(\mathrm{OR}=2.90,95 \% \mathrm{Cl} 1.60-5.28, \mathrm{p}=0.002)$, traditional self treatment $(O R=1.36,95 \% \mathrm{Cl} 0.93-2.00, p=0.128)$, medicine taken for hypertension $(\mathrm{OR}=2.07,95 \% \mathrm{Cl} 1.05-4.10$, $\mathrm{p}=0.058)$, medicine taken for cholesterol $(O R=5.62,95 \% \mathrm{Cl}$ $2.81-11.23, p=0.000$ ) were possibly associated with CKD among women in Indonesia.

Multiple logistic regression used for multivariable analysis to get final model in this study. The result revealed that cardiovascular (adj. OR $=4.42,95 \% \mathrm{Cl} 2.54-7.70, \mathrm{p}=<0.001$ ); cholesterol (adj. OR $=2.64,95 \% \mathrm{Cl} 1.68-4.15, \mathrm{p}=<0.001$ ) were significantly associated with CKD among women in Indonesia. Other significant covariate were age $>50$ years old (adj. OR = $2.01,95 \% \mathrm{Cl} 1.30-3.12, \mathrm{p}=0.002$ ); overweight $/$ obese (adj. OR $=2.01,95 \% \mathrm{Cl} 1.03-2.14, \mathrm{p}=0.034$ ); smoking (adj. OR = 2.25, $95 \% \mathrm{Cl} 1.22-4.15, \mathrm{p}=0.010)$.

\section{DISCUSSION}

This study revealed that the prevalence of CKD among women in Indonesia was $1.07 \%$. It was different from the previous study that showed the result of the prevalence of CKD among women in Indonesia was $2.4 \%$ (10). It might be the

Table 3. Factor Associated with Chronic Kidney Disease among Women in Indonesia by using Simple Logistic Regression ( $\mathrm{n}=$ 14,141)

\begin{tabular}{|c|c|c|c|c|c|c|}
\hline \multicolumn{2}{|c|}{ Characteristic } & Number & $\%$ of CKD & OR & $95 \% \mathrm{Cl}$ & P Value \\
\hline \multicolumn{7}{|c|}{ Sociodemographic } \\
\hline \multirow{3}{*}{ Age } & $<35$ & 6,904 & 0.61 & 1 & & \multirow{3}{*}{$<0.001$} \\
\hline & $>=35-<50$ & 4,479 & 1.34 & 2.22 & $1.49-3.30$ & \\
\hline & $>=50$ & 2,758 & 1.78 & 2.96 & $1.95-4.47$ & \\
\hline \multirow{2}{*}{ Marital Status } & Single & 2,964 & 0.78 & 1 & & \multirow{2}{*}{0.071} \\
\hline & Married & 11,177 & 1.15 & 1.48 & $0.95-2.31$ & \\
\hline \multirow{4}{*}{ Education } & University & 2,202 & 0.95 & 1 & & \multirow{4}{*}{0.439} \\
\hline & Senior High School & 4,132 & 0.92 & 096 & $0.56-1.65$ & \\
\hline & Junior High School & 2,856 & 1.05 & 1.10 & $0.63-1.93$ & \\
\hline & Elementary & 4,951 & 1.25 & 1.31 & $0.80-2.17$ & \\
\hline \multirow{2}{*}{ Ethnicity } & Javanese & 9,546 & 1.14 & 1 & & \multirow{2}{*}{0.210} \\
\hline & Others & 4,595 & 0.91 & 1.25 & $0.88-1.79$ & \\
\hline \multirow{2}{*}{ Residence } & Urban & 8,499 & 1.01 & 1 & & \multirow{2}{*}{0.428} \\
\hline & Rural & 5,642 & 1.15 & 0.88 & $0.63-1.21$ & \\
\hline \multirow{2}{*}{ Body Mass Index } & Underweight / Normal Weight & 5,821 & 0.74 & 1 & & \multirow{2}{*}{0.001} \\
\hline & Overweight / Obese & 8,320 & 1.30 & 1.77 & $1.24-2.52$ & \\
\hline \multicolumn{7}{|c|}{ Metabolic Disease } \\
\hline \multirow{2}{*}{ Hypertension } & No & 12,123 & 0.92 & 1 & & \multirow{2}{*}{0.000} \\
\hline & Yes & 2,018 & 1.93 & 2.11 & $1.46-3.05$ & \\
\hline \multirow{2}{*}{ Diabetes } & No & 13,828 & 1.01 & 1 & & \multirow{2}{*}{0.000} \\
\hline & Yes & 313 & 3.83 & 3.93 & $2.15-7.16$ & \\
\hline \multirow{2}{*}{ Cardiovascular } & No & 13,875 & 0.97 & 1 & & \multirow{2}{*}{$<0.001$} \\
\hline & Yes & 266 & 6.02 & 6.51 & $3.82-11.10$ & \\
\hline \multirow{2}{*}{ Cholesterol } & No & 13,419 & 0.92 & 1 & & \multirow{2}{*}{$<0.001$} \\
\hline & Yes & 722 & 3.74 & 4.17 & $2.73-6.36$ & \\
\hline \multicolumn{7}{|c|}{ Behaviour } \\
\hline \multirow{2}{*}{ Smoking } & No & 13,725 & 1.01 & 1 & & \multirow{2}{*}{0.002} \\
\hline & Yes & 416 & 2.88 & 2.90 & $1.60-5.28$ & \\
\hline \multirow{2}{*}{ Modern Self Treatment } & No & 7,045 & 1.15 & 1 & & 0345 \\
\hline & Yes & 7,096 & 0.99 & 0.86 & $0.62-1.18$ & 0.345 \\
\hline Traditional Solf Treatment & No & 11,643 & 1.00 & 1 & & 0128 \\
\hline Iraaitionat seti treatment & Yes & 2,498 & 1.36 & 1.36 & $0.93-2.00$ & 0.128 \\
\hline Medicine Taken for & No & 13,717 & 1.04 & 1 & & 0058 \\
\hline Hypertension & Yes & 424 & 2.12 & 2.07 & $1.05-4.10$ & 0.050 \\
\hline Medicine Taken for & No & 13,976 & 1.02 & 1 & & \\
\hline Cholesterol & Yes & 165 & 5.45 & 5.62 & $2.81-11.23$ & 0.000 \\
\hline
\end{tabular}


Table 4. Multivariable Analysis using Multiple Logistic Regression for Factor Associated with Chronic Kidney Disease among Women in Indonesia $(n=14,141)$

\begin{tabular}{|c|c|c|c|c|c|c|c|}
\hline \multicolumn{2}{|c|}{ Characteristic } & Number & $\%$ of CKD & Crude OR & Adjusted OR & $95 \% \mathrm{Cl}$ & P-Value \\
\hline \multirow{2}{*}{ Cardiovascular } & No & 13,875 & 0.97 & 1 & 1 & & \multirow{2}{*}{$<0.001$} \\
\hline & Yes & 266 & 6.02 & 6.51 & 4.42 & $2.54-7.70$ & \\
\hline \multirow{2}{*}{ Cholesterol } & No & 13,419 & 0.92 & 1 & 1 & & \multirow{2}{*}{$<0.001$} \\
\hline & Yes & 722 & 3.74 & 4.17 & 2.64 & $1.68-4.15$ & \\
\hline \multirow{3}{*}{ Age } & $<35$ & 6,904 & 0.61 & 1 & 1 & & \multirow{3}{*}{0.002} \\
\hline & $>=35-<50$ & 4,479 & 1.34 & 2.22 & 1.79 & $1.19-2.69$ & \\
\hline & $>=50$ & 2,758 & 1.78 & 2.96 & 2.01 & $1.30-3.12$ & \\
\hline \multirow{2}{*}{ Body Mass Index } & Underweight / Normal Weight & 5,821 & 0.74 & 1 & 1 & & \multirow{2}{*}{0.034} \\
\hline & Overweight / Obese & 8,320 & 1.30 & 1.77 & 1.48 & $1.03-2.14$ & \\
\hline \multirow{2}{*}{ Smoking } & No & 13,725 & 1.01 & 1 & 1 & & \multirow{2}{*}{0.010} \\
\hline & Yes & 416 & 2.88 & 2.90 & 2.25 & $1.22-4.15$ & \\
\hline
\end{tabular}

previous study had a specific population only among diabetes mellitus patients. Other previous study from neighbor countries found that women in Malaysia had a prevalence of CKD 17.3\%, and Thailand 9.3\% (11,12). It might be different from the present study because of the study from Malaysia only specific in West Malaysia. A study from Thailand might be different from this study because Thailand has a different area and culture with Indonesia.

Cardiovascular disease and chronic kidney disease have very close links. It is known from previous studies that cardiometabolic risk and disease are only; it became one of the biggest causes of death. This is because kidney disease causes damage to other organs, including the heart and vice versa, causing the failure of both organs, either the heart or kidneys. Cardiovascular disease will greatly worsen the condition of patients with kidney failure with end-stage kidney disease (ESRD). Associated with disorders of mineral metabolism and vitamin $D$, there are several factors that can affect both kidney failure and heart disease.

Moreover, patients with kidney disease have a very close relationship with kidney failure. This is certainly greatly influenced by the metabolic system in the body, which is also the most important factor in kidney and heart disease. It was explained that uremic poisons, which are bound to dialyzable proteins such as indoxyl sulfate and p-cresyl sulfate, which are produced by colonic microbes from food amino acids, seem to cause kidney dysfunction. Thus, a therapeutic approach that targets colonic microbiota has led to new prospects in early intervention for CKD patients (13). Other previous studies found that cardiovascular disease in women $(\mathrm{HR}=1.62,95 \% \mathrm{Cl}$, 1.10 - 2.39) (14).

People will experience narrowing of the arteries when they have kidney disease compared to healthy people. So that cholesterol becomes a very important factor in chronic kidney disease. In fact, this is also one of the factors causing kidney failure at an initial level. Handling patients in kidney failure with high cholesterol will certainly be different from handling patients without complications of cholesterol disease. This is due to the role of the body's metabolic system, which contributes to blood vessel diseases such as calcium minerals, vitamin D. and phosphate. So that cholesterol becomes a thing that has a major contribution to metabolic diseases such as heart disease, which certainly has to do with kidney failure. Previous studies in paired and network meta-analyses on the relationship between the efficacy of statin use with or without ezetimibe and the reduction of low-density lipoprotein cholesterol (LDLC) and C-reactive protein (CRP) in patients with chronic kidney disease (CKD) are presented. Evaluation of the benefits of the drug can lead to individual therapy for CKD patients: Lowering cholesterol for CKD patients with high LDLC and CRP levels is recommended (15). Moreover, other previous study found that both hypercholesterolemia and low highdensity lipoprotein cholesterol (HDL-C) were independently associated with albuminuria $(\mathrm{OR}=1.49,95 \% \mathrm{Cl} 1.08-2.07$ and $\mathrm{OR}=1.53,95 \% \mathrm{Cl} 1.13-2.09$, respectively) (16).

The prevalence of CKD rises dramatically with age. All organs will walk aging with the strength of its function, which is physiologically also aging, including even the kidney organs. An aging kidney condition is often at risk for chronic kidney failure. Normally, by using certain measurements, generally, the kidney organ function is found to be in the range of 100 $\mathrm{cc} /$ minute. But along with the passage of the human life cycle, kidney function will become $60 \mathrm{cc} /$ minute when entering old age and even goes down again according to the physiological curve. Decreased kidney function to $60 \mathrm{cc} /$ minute is still classified as a normal process because there is a mechanism of the aging process (17). The decreased estimated glomerular filtration rate (eGFR) in parallel with age has been known for decades (18). The previous study by Hare et al. (2007) reported that a major effect modifier among patients with an eGFR of $<60 \mathrm{ml} / \mathrm{min}$ per $1.73 \mathrm{~m}^{2}$ is age. That study recommends us to move beyond the same stage-based approach to manage chronic kidney disease (19).

Obesity can attack a person with chronic kidney disease. Every day around the world, one of 10 people suffering from chronic kidney disease is obesity. Obesity compels the kidneys to work harder and filter more blood than usual to comply with metabolic demands that go up depending on body weight. As a result, damage to the kidneys occurs, and a person is exposed to the risk of chronic kidney disease for a long time. People with obesity are 83 percent at risk of suffering from chronic kidney disease compared to normal weight owners (20). Being overweight is one of the risk factors of CKD. This is in line with previous research, which revealed that obesity substantially raises the risk of CKD and even remains true for those with and without diabetes, hypertension, or cardiovascular disease. So it is suggested to reduce weight among those who are overweight, and those who are obese can reduce the risk of CKD, with each BMI reduction unit resulting in relatively similar risk reduction (21). A high body mass index is one of the strongest risk factors for new-onset CKD. In obese individuals, compensated hyperfiltration occurs to meet the increased metabolic demands of body weight. Increased intraglomerular pressure can damage the kidneys and increase the risk of developing CKD in the long-term (22). 
Smoking is an independent risk factor for CKD. Compared with never-smokers, People who ever-smokers were 1.27 (95\% $\mathrm{Cl} 1.19-1.35)$ and current smoker 1.34 (95\% Cl 1.23-1.47) (23). Smoking is a factor that indirectly damages the kidney organs. This is due to the nicotine contained in cigarette content can interfere with filtration and the working system of the kidneys. Smoking can interfere with drugs used to treat high blood pressure. The main cause of kidney disease lies in uncontrolled blood pressure. While smoking slows blood flow to vital organs and can worsen existing kidney disease. So indirectly, smoking is a major factor causing kidney failure (24).

\section{CONCLUSION}

This study found a slight prevalence of Chronic Kidney Disease (CKD) in a representative sample of women population in Indonesia. Cardiovascular and cholesterol were statistically significant with chronic kidney disease. Other significant covariates were age, body mass index, and smoking.

\section{ACKNOWLEDGEMENT}

The research used the data of the IFLS- 5 conducted by RAND (http://www.rand.org/labor/FLS/IFLS.html). We would like to express our sincere appreciation for RAND for allowing access to the survey data as well as the study participants who provided the survey data.

\section{Ethical Consideration}

The IFLS has been reviewed and approved by Institutional Review Boards, the United States, and Gadjah Mada University, Indonesia.

\section{REFERENCES}

1. GDB. Global, regional, and national incidence, prevalence, and years lived with disability for 310 diseases and injuries, 1990-2015: a systematic analysis for the Global Burden of Disease Study 2015. Lancet, 2017;388(10053):1545-602. https://doi.org/10.1016/S0140-6736(16)31678-6

2. Piccoli GB, Alrukhaimi M, Liu Z, Zakharova E, Levin A. What we do and do not know about women and kidney diseases; questions unanswered and answers unquestioned: reflection on World Kidney Day and International Woman's Day. BMC Nephrology 2018;19(66):1-11. https://doi.org/10.1186/s12882-018-0864-y PMid:29544451 PMCid:PMC5856379

3. CDC. National Chronic Kidney Disease Fact Sheet. National Center for Chronic Disease Prevention and Health Promotion. 2017.

4. Ford H. Chronic Kidney Disease (CKD). Clinical Practice Recommendations for Primary Care Physicians and Healthcare Providers (6th Ed.; H. F. H. System., ed.). United Stated. 2011.

5. Couser WG, Remuzzi G, Mendis S, Tonelli M. The contribution of chronic kidney disease to the global burden of major noncommunicable diseases. Kidney International, 2011;80(12):1258-70. https://doi.org/10.1038/ki.2011.368 PMid:21993585

6. Mills KT, Xu Y, Zhang W, Bundy JD, Chen C, Kelly TN, ... He $\mathrm{J}$. A systematic analysis of worldwide population-based data on the global burden of chronic kidney disease in 2010. International Society of Nephrology, 2015:950-7. https://doi.org/10.1038/ki.2015.230 PMid:26221752 PMCid:PMC4653075

7. Prodjosudjadi W, Suhardjono, Suwitra K, Pranawa. Detection and prevention of chronic kidney disease in Indonesia: Initial community screening. Nephrology, 2009;14:669-74. https://doi.org/10.1111/j.1440-1797.2009. 01137.x PMid:19796026

8. Peltzer K, Pengpid S. Prevalence, risk awareness and health beliefs of behavioural risk factors for cardiovascular disease among university students in nine ASEAN countries. BMC Public Health. 2018. https://doi.org/10.1186/s12889-018-5142-1 PMid:29433473 PMCid:PMC5810026

9. Hosmer D, Lemeshow S. Applied logistic regression (2nd edn.). New York: Willey. 2000. https://doi.org/10.1002/ 0471722146 PMid:10886529

10. Jardine MJ, Mahaffey KW, Neal B, Agarwal R, Bakris GL, Brenner BM, ... Yunir E. Prevalence of kidney dysfunction in diabetes mellitus and associated risk factors among productive age Indonesian. Journal of Diabetes and Metabolic Disorders, 2018;17(6):53-61. https://doi.org/ 10.1159/000484633 PMid:29253846 PMCid:PMC5804835

11. Hooi LS, Ong LM, Ahmad G, Bavanandan S, Ahmad NA, Naidu BM, et al. A population-based study measuring the prevalence of chronic kidney disease among adults in West Malaysia. Kidney International, 2013;84(5):1034-40. https://doi.org/10.1038/ki.2013.220 PMid:23760287

12. Thakkinstian A, Chaiprasert A, Hospital P, Sangthawan $P$, Ongaiyooth L. Prevalence and risk factors of chronic kidney disease in the Thai adult population: Thai SEEK study Prevalence and risk factors of chronic kidney disease in the Thai adult population: Thai SEEK study. Nephrology Dialysis Transplantation, 2010;(May). https://doi.org/ 10.1093/ndt/gfp669 PMid:20037182

13. Liu M, Li X, Lu L, Cao Y, Sun R, Chen S. Cardiovascular disease and its relationship with chronic kidney disease. European Review for Medical and Pharmacological Sciences, 2014:2918-26.

14. Ninomiya T, Kiyohara Y, Kubo M, Tanizaki Y, Doi Y, Okubo K, et al. Chronic kidney disease and cardiovascular disease in a general Japanese population: The Hisayama Study. Department of Medicine and Clinical Science, Graduate School of Medical Sciences, Kyushu University, Fukuoka, Japan, 2005;68:228-36. https://doi.org/10.1111/j.15231755.2005.00397.x PMid:15954912

15. Herrera-gómez F, Martín-garcía D. Cholesterol-Lowering Treatment in Chronic Kidney Disease: Multistage Pairwise and Network Meta- Analyses. Scientific Reports, 2019;(October 2018):1-11. https://doi.org/10.1038/s41598019-45431-5 PMid:31222137 PMCid:PMC6586647

16. Liu D, Wan J, Liu Z, Wang P, Cheng G, Shi X. Association between dyslipidemia and chronic kidney disease: a crosssectional study in the middle-aged and elderly Chinese. Department of Nephrology, The First Affiliated Hospital, Zhengzhou University, Zhengzhou, Henan 450052, China, 2013;126(7).

17. Prakash S, O'Hare AM. Interaction of Aging and CKD. Semin Nephrol. 2009 September 2010;29(5):497-503. https://doi.org/10.1016/j.Semnephrol.2009.06.006 PMid:19751895 PMCid:PMC2771919

18. Tonelli M, Riella M. Chronic kidney disease and the aging population. Department of Medicine, University of Alberta, 
2014:1-5. https://doi.org/10.5935/0101-2800.20140001 PMid:24676606

19. Hare AMO, Choi Al, Bertenthal D, Bacchetti P, Garg AX, Kaufman JS, et al. Age Affects Outcomes in Chronic Kidney Disease. American Society of Nephrology 2007;8:2758-65. https://doi.org/10.1681/ASN.2007040422 PMid:17855638

20. Abdu J, Kahssay M, Gebremedhin M. Household Food Insecurity, Underweight Status, and Associated Characteristics among Women of Reproductive Age Group in Assayita District, Afar Regional State, Ethiopia. Journal of Environmental and Public Health, 2018. https://doi.org/10.1155/2018/7659204ＰMid:29887896 PMCid:PMC5977031

21. Herrington WG, Smith M, Bankhead C, Matsushita K, et al. Body-mass index and risk of advanced chronic kidney disease: Prospective analyses from a primary care cohort of 1.4 million adults in England. PLoS Medicine, 2017:1-15. https://doi.org/10.1371/journal.pone.0173515

PMid:28273171 PMCid:PMC5342319
22. Kovesdy CP, Furth SL, Zoccali C. Obesity and Kidney Disease: Hidden Consequences of the Epidemic. Canadian Journal of Kidney Health and Disease, 2017;4:1-10. https://doi.org/10.1177/2054358117698669 PMid:28540059 PMCid:PMC5433675

23. Xia J, Wang L, Ma Z, Zhong L, Wang Y, Gao Y, ... Su X. Cigarette smoking and chronic kidney disease in the general population: a systematic review and meta-analysis of prospective cohort studies. Nephrol Dial Transplant 2017;32:475-87. https://doi.org/10.1093/ndt/gfw452 PMid:28339863

24. Yacoub R, Habib H, Lahdo A, et al. Association between smoking and chronic kidney disease: a case control study. BMC Public Health, 2010;10(1):731. https://doi.org/10.1186/1471-2458-10-731 PMid:21108832 PMCid:PMC3004836 